\title{
In vitro pharmacological evaluation of the radiolabeled C-terminal substance P analogue Lys-Phe-Phe-Gly-Leu-Met-NH2: Does a specific binding site exist?
}

\author{
Aleksandra Tomczyszyn ${ }^{1}$, Balazs Csibrany ${ }^{2}$, Attila Keresztes², Jayapal Reddy Mallareddy ${ }^{2}$, Jolanta Dyniewicz ${ }^{3}$, \\ Aleksandra Misicka1,3, Geza Toth ${ }^{2}$, Andrzej W. Lipkowski ${ }^{3,4}$ \\ ${ }^{1}$ Faculty of Chemistry, Biological and Chemical Research Centre, University of Warsaw, Warsaw, Poland, ${ }^{2}$ Hungarian Academy \\ of Sciences, Biological Research Center, Institute of Biochemistry, Szeged, Hungary, ${ }^{3}$ Department of Neuropeptides, Mossakowski \\ Medical Research Centre, Polish Academy of Sciences, Warsaw, Poland, ${ }^{4}$ Tufts University School of Medicine, Boston, MA, USA
}

\begin{abstract}
In the present paper, we report the synthesis, radiolabeling and comprehensive pharmacological evaluation of a C-terminally truncated tachykinin derivative, ${ }^{3} \mathrm{H}-\mathrm{KFFGLM}-\mathrm{NH}_{2}$. The C-terminal fragments of endogenous tachykinins are pharmacophores responsible for interaction with the tachykinin receptors NK1, NK2 and NK3. The N-terminal fragments are responsible for modulation of receptor selectivity and interactions with other receptor systems. To evaluate and separate the function of an NK-pharmacophore from the activity of its parent neurokinin, KFFGLM-NH was synthesized in both tritiated and unlabeled forms. It has been proposed that the obtained NK-binding profiles of specific reference ligands and KFFGLM-NH ${ }_{2}$ differentiate monomeric and dimeric forms of NK receptors. We hypothesize that dimers of NK receptors could be specific receptor(s) for C-terminal fragments of all neurokinins as well as their C-terminal fragments, including H-KFFGLM-NH${ }_{2}$. Dissociation of dimers into monomers opens access to additional allosteric binding sites. Fully elongated undecapeptide substance $P$ interacts with both the "tachykinin pocket" and the "allosteric pocket" on the monomeric NK1 receptor, resulting in high and selective activation. However, C-terminal hexapeptide fragment analogues, recognizing only the "tachykinin pocket", may have less specific interactions with all tachykinin receptors in both monomeric and dimeric forms.
\end{abstract}

Key words: neurokinin (tachykinin), receptor binding, radioligand, GPCR monomer, dimer, allosteric modulation.

\section{Introduction}

The history of mammalian tachykinin discovery begins in 1931, when von Euler and Gaddum isolated a peptide from a preparation of equine brain and intestine. They characterized this peptide and named it "substance P". Further studies revealed that sub- stance P caused vasodilation and stimulation of gut motility in rabbits. It was another 40 years before the amino acid sequence of substance $P$ was confirmed. At that time, it was recognized that the sequence of substance $P$ is similar to those of the tachykinins eledoisin and physalaemin, which were isolated from invertebrates [28]. Other endogenous tachyki- 
nins (neurokinins A and B and hemokinin-1) have been discovered more recently in vertebrates [19]. Primary structure activity relationship (SAR) studies on invertebrate tachykinins led to the conclusion that $\mathrm{C}$-terminal hexapeptide amide fragments are fully responsible for the tachykinin-like properties [1]. Further SAR studies on mammalian tachykinins also confirmed that the active fragments of tachykinins (pharmacophores) have a common $C$-terminal sequence of Y-Phe-X-Gly-Leu-Met- $\mathrm{NH}_{2}$, where $\mathrm{Y}$ is any non-lipophilic amino acid residue and $X$ is a lipophilic alkyl (Val, Ile) or aromatic (Tyr, Phe) residue [11]. Three tachykinin receptors, termed $\mathrm{NK}_{1}, \mathrm{NK}_{2}$ and $\mathrm{NK}_{3}$, were identified in the late 1980s as G-protein-coupled receptors (GPCR). The $\mathrm{N}$-terminal fragments, as well as the type of lipophilic amino acid residue in the $C$-terminal fragments, modulate NK-receptor selectivity. The $\mathrm{N}$-terminal fragments of tachykinins play a particularly important role in modulating selectivity. The nature of these fragments decreases or increases affinities to particular NK receptor types, resulting in highly selective endogenous ligands. The order of affinities for different tachykinin receptors toward mammalian tachykinins is as follows: for $\mathrm{NK}_{1}, \mathrm{SP}>\mathrm{NK} A>\mathrm{NKB}$; for $\mathrm{NK}_{2}, \mathrm{NKA}>\mathrm{NKB}>\mathrm{SP}$; for $\mathrm{NK}_{3}$, $N K B>N K A>S P$. Recently, a new chimeric type of GPCR ligand has been proposed that hybridizes pharmacophores from different receptor types into one molecule [10]. The $C$-terminal fragments of tachykinins, or their analogues, have been hybridized with opioid pharmacophores to develop a new type of analgesic $[6,7,11,15,16]$. In multitarget receptor ligands it is important to evaluate the role of each separated target component. Therefore, we decided to synthesize and evaluate the C-terminal fragment of tachykinin to identify specific roles for tachykinin pharmacophores. The first amino acid in the C-terminal hexapeptide fragment is glutamine, which can be transformed easily to pyroglutamine. Both the $\mathrm{N}$-terminal hexapeptide and its pyroglutamine analogue have very limited solubility in aqueous media. This creates the requirement that special solvents (DMSO or DMF) or carriers (dextran, cyclodextrin, albumin, etc.) be used for biological studies on these peptides. We thus decided to synthesize Lys-[SP $\left.{ }_{7-11}\right]$ as a prospective tachykinin pharmacophore standard. This compound was originally synthesized as an analogue of the non-mammalian tachykinin eledoisin, long before the sequence of substance $P$ had been established [12]. In comparison with the activity of substance P, Lys-[SP $7-11$ shows a $200 \%$ greater hypotensive effect in dogs and $100 \%$ greater GPI contraction. These results suggest that the pharmacological properties of this compound are similar to those of substance $P$.

\section{Material and methods Chemicals}

Protected amino acids were purchased from Sigma Aldrich, Merck Chemicals and Bachem. Coupling reagents were obtained from Sigma Aldrich. All reagents and solvents were of reagent grade and were used without further purification. The mobile phases for linear gradient elution in RP-HPLC contained $0.05 \%$ trifluoroacetic acid (TFA) in water or acetonitrile. The stationary phase was a Jupiter Proteo C12 column. A Shimadzu LC-MS liquid chromatograph with an attached ESI mass spectrometer was used to identify the peptides.

Selective neurokinin receptor ligands such as substance P, L-703,606, $\left(\mathrm{Nle}^{10}\right)$-neurokinin A (4-10), (Tyr $\left.{ }^{5}, \mathrm{D}-\mathrm{Trp}^{6,8,9}, \mathrm{Lys}^{6}-\mathrm{NH}_{2}{ }^{10}\right)$-neurokinin A (4-10), ( $\left.\mathrm{Pro}^{7}\right)$ neurokinin B and (Trp $\left.{ }^{7}, \beta-A l a^{8}\right)$-neurokinin A (4-10) were purchased from Bachem (Budapest, Hungary). Unlabeled H-Lys-Phe-Phe-Gly-Leu-Met-NH ${ }_{2}$ (H-KFF$\mathrm{GLM}-\mathrm{NH}_{2}$ ) and its halogenated precursor were synthesized in our laboratories. Tris-hydroxymethylaminomethane (Tris, free base), polyethylenimine (PEI), ethylene glycol-bis(2-aminoethylether)-N,N, $N^{\prime}, N^{\prime}$-tetraacetic acid (EGTA), guanosine-5'-diphosphate sodium salt (GDP), guanosine $5^{\prime}$-[ $\gamma$-thio] triphosphate tetralithium salt (GTP $\gamma$ ), Bradford reagent, bovine serum albumin (BSA), magnesium chloride hexahydrate $\left(\mathrm{MgCl}_{2} \times 6 \mathrm{H}_{2} \mathrm{O}\right)$, protease inhibitor cocktail (P8340), manganese chloride tetrahydrate $\left(\mathrm{MnCl}_{2} \times 4 \mathrm{H}_{2} \mathrm{O}\right)$ and $\mathrm{HCl}(37 \%)$ were purchased from Sigma Aldrich, Ltd. (Budapest, Hungary). Sodium chloride $(\mathrm{NaCl})$ and sucrose were obtained from Molar, Ltd. and Fluka (Budapest, Hungary). The tritiated radioligand $\left[{ }^{3} \mathrm{H}\right]-\mathrm{KFFGLM}-\mathrm{NH}_{2}(0.9 \mathrm{TBq} / \mathrm{mmol}$, $24 \mathrm{Ci} / \mathrm{mmol}$ ) was prepared locally (Hungarian Academy of Sciences, Biological Research Center, Institute of Biochemistry, Isotope Laboratory) using the appropriate halogenated peptide derivative. Stabilized [ $\left.{ }^{35} \mathrm{~S}\right] \mathrm{GTP} \gamma \mathrm{S}(37 \mathrm{TBq} / \mathrm{mmol}$, $1000 \mathrm{Ci} / \mathrm{mmol})$ was purchased from Isotope Institutes, Ltd. (Budapest, Hungary). The tritium used for the radiolabeling of the precursor peptides was imported from Techsnabexport (Moscow, Russia). All other reagents were of analytical grade. 


\section{Synthesis, purification and structure determination of $\mathrm{H}$-KpIFpIFGLM-NH and $\mathrm{H}-\mathrm{KFFGLM}-\mathrm{NH}_{2}$}

Peptides were synthesized manually on Rink Amide resin through a standard Fmoc/tBu solid phase protocol. $\mathrm{N}^{\alpha}-\mathrm{Fmoc}$ chemistry was employed using $\mathrm{N}$-hydroxybenzotriazole and $\mathrm{O}$-(benzotriazol1 -yl)-N,N,N'N'-tetramethyluronium tetrafluoroborate as the coupling reagents for peptide elongation. The peptide was cleaved from the resin with concomitant side chain deprotection by treatment of the resin with a solution of TFA/TIS/ $\mathrm{H}_{2} \mathrm{O} 19: 1: 1$ $(20 \mathrm{ml} / 1 \mathrm{~g}$ resin). HPLC analyses and purifications were carried out using C12 analytical (Jupiter 4u Proteo $90 \mathrm{~A}, 250 \times 4.6 \mathrm{~mm}, 4 \mu \mathrm{m})$ and C12 semipreparative (Jupiter 4u Proteo 90A, $250 \times 10 \mathrm{~mm}, 4 \mu \mathrm{m}$ ) columns on a Shimadzu instrument. ESI-MS analyses were performed on a Shimadzu instrument.

\section{Radiolabeling of the $\mathrm{N}$-terminally truncated neurokinin hexapeptide derivative $\left[{ }^{3} \mathrm{H}\right]-\mathrm{KFFGLM}-\mathrm{NH}_{2}$}

The halogenated hexapeptide precursor was tritiated by the general method reported previously [31]. The halogenated precursor H-Lys-plPhe-plPhe-GlyLeu-Met- $\mathrm{NH}_{2}$ (3.6 mg, $\left.2.95 \mu \mathrm{mol}\right)$ was dissolved in DMF $(1 \mathrm{ml})$. To this solution was added $\mathrm{PdO} / \mathrm{BaSO}_{4}$ catalyst $(10 \mathrm{mg})$ and triethylamine (TEA, $5 \mu \mathrm{l})$. The reaction mixture was stirred for $1 \mathrm{~h}$ in the presence of ${ }^{3} \mathrm{H}_{2}$ at room temperature. When the reaction was complete, the mixture was filtered through a Whatman GF/C glass fiber filter and washed several times with EtOH: $\mathrm{H}_{2} \mathrm{O}(1: 1, \mathrm{v} / \mathrm{v})$ to remove the catalyst and labile tritium. The total activity of the crude product was determined in a toluene-based scintillation cocktail using a TRI-CARB 2100TR Liquid Scintillation Counter (Canberra-Packard, PerkinElmer Life Sciences, 549 Albany Street, Boston, MA 02118), and was found to be $110 \mathrm{mCi}(4.1 \mathrm{GBq})$. The crude [ $\left.{ }^{3} \mathrm{H}\right]-\mathrm{KFF}-$ $\mathrm{GLM}-\mathrm{NH}_{2}$ was then purified by RP-HPLC, and its purity was determined to be greater than $95 \%$. Specific radioactivity was found to be $24 \mathrm{Ci} / \mathrm{mmol}(0.89 \mathrm{TBq} /$ $\mathrm{mmol}$ ). The radioligand was taken up in spectroscopic grade ethanol containing $0.1 \mathrm{mM} \mathrm{L-Met}$ and stored in liquid nitrogen.

\section{Rat brain membrane preparation}

Rats (male and female Wistar, 250-300 g, 2-3 months old) were kept in groups of four under stan- dard conditions with access to food and water ad libitum. The animals were handled according to the guidelines of the European Communities Council Directives (86/609/ECC) and the Hungarian Act for the Protection of Animals in Research (XXVIII. tv. Section 32). Crude membranes of rat brains without cerebellums were prepared by a standard protocol as described earlier [2]. The brain homogenates were kept frozen in liquid nitrogen. On the day of the experiment, rat brain homogenates were thawed, diluted with working buffer and centrifuged at 20,000 $\times \mathrm{g}$ to remove sucrose. The pellet was homogenized with a Dounce homogenizer in an appropriate volume of binding buffer (50 mM Tris- $\mathrm{HCl}, \mathrm{pH} 7.4,0.1 \% \mathrm{BSA}$, $3 \mathrm{mM} \mathrm{MnCl}_{2}$ and protease inhibitor). Protein content was determined using the Bradford assay with BSA as the standard.

\section{Radioligand binding assays}

All binding experiments were carried out at $25^{\circ} \mathrm{C}$ in a final volume of $1 \mathrm{ml}$ containing $0.3-0.5$ $\mathrm{mg} / \mathrm{ml}$ membrane in neurokinin buffer. This buffer consisted of $50 \mathrm{mM}$ Tris- $\mathrm{HCl}$ (pH 7.4), 0.1\% BSA, $3 \mathrm{mM} \mathrm{MnCl}$, and protease inhibitor. In the kinetic experiments, the time course of association was measured by incubating $2.0 \mathrm{nM}\left[{ }^{3} \mathrm{H}\right]-\mathrm{KFFGLM}-\mathrm{NH}_{2}$ with the protein for 60 minutes. In the dissociation experiments, the radioligand was pre-incubated with the membrane until equilibrium was reached (60 minutes). A solution of $10 \mu \mathrm{M}$ unlabeled H-KFF$\mathrm{GLM}-\mathrm{NH}_{2}$ was then added to induce dissociation of the radioligand. This process was typically complete after 60 minutes. Saturation binding experiments to determine the equilibrium dissociation constant $\left(K_{d}\right)$ and maximum number of binding sites $\left(B_{\max }\right)$ were performed with increasing concentrations (0.1$10 \mathrm{nM})$ of $\left[{ }^{3} \mathrm{H}\right]-\mathrm{KFFGLM}-\mathrm{NH}_{2}$. Homologous and heterologous competition binding experiments were carried out by incubation of rat brain membranes with $3 \mathrm{nM}\left[{ }^{3} \mathrm{H}\right]-\mathrm{KFFGLM}-\mathrm{NH}_{2}$ in the presence of increasing concentrations $\left(10^{-10}-10^{-5} \mathrm{M}\right)$ of unlabeled neurokinin ligands. Non-specific binding was determined with $10 \mu \mathrm{M} \mathrm{H}$-KFFGLM-NH $\mathrm{N}_{2}$ and subtracted from the total binding to obtain specific binding. Incubations were terminated by the addition of ice-cold buffer (50 mM Tris- $\mathrm{HCl}, \mathrm{pH}: 7.4,0.05 \%$ BSA). A Brandel Cell Harvester (Gaithersburg, MD, USA) was then used to filter cells rapidly with Whatman GF/B glass fiber filters pre-soaked in PEl. Filters were immersed directly in Optiphase Supermix scintillation cocktail 
(PerkinElmer) and assessed in a TRI-CARB 2100TR liquid scintillation counter. The results presented are mean values \pm SEM of at least five independent experiments, each performed in duplicate. Kinetic data were calculated to obtain the rate constants for association $\left(k_{a}\right)$ and dissociation $\left(k_{d}\right)$. Non-linear regression analysis of direct saturation isotherms was used to obtain values for the equilibrium dissociation constant $\left(\mathrm{K}_{\mathrm{d}}\right)$ and receptor density $\left(\mathrm{B}_{\max }\right)$. Inhibitory constants $\left(K_{i}, n M\right)$ were calculated from competition binding experiments using non-linear least-square curve fitting and the Cheng-Prusoff equation with GraphPad Prism software (version 4.0, San Diego, CA, USA) [5].

\section{Ligand-stimulated $\left[{ }^{35} \mathrm{~S}\right] \mathrm{GTP} \gamma \mathrm{S}$ functional assay}

Rat brain membrane homogenates (10-15 $\mu \mathrm{g}$ protein/tube) were incubated with $0.05 \mathrm{nM}\left[{ }^{35} \mathrm{~S}\right] \mathrm{GTP} \gamma \mathrm{S}$ and $10^{-10}-10^{-5} \mathrm{M}$ unlabeled ligand agonists and/or $10^{-6} \mathrm{M}$ (final concentration) receptor specific antagonists in the presence of $30 \mu \mathrm{M} \mathrm{GDP}, 100 \mathrm{mM} \mathrm{NaCl}$, $3 \mathrm{mM} \mathrm{MgCl}$ and $1 \mathrm{mM}$ EGTA in Tris- $\mathrm{HCl}$ buffer $(50 \mathrm{mM}$, $\mathrm{pH}$ : 7.4) for 60 minutes at $30^{\circ} \mathrm{C}$. Basal binding was determined in the absence of ligands and normalized to $100 \%$. Nonspecific binding was determined with $10 \mu \mathrm{M}$ unlabeled GTP $\gamma \mathrm{S}$ and subtracted from total binding to yield specific binding. Reaction mixtures were filtered onto GF/B glass fiber filters using a Brandel Cell Harvester (Gaithersburg, MD, USA). Filter-bound radioactivity was determined in Optiphase Supermix scintillation cocktail (PerkinElmer) using a TRI-CARB 2100TR Liquid Scintillation Counter (Canberra-Packard, PerkinElmer Life Sciences, 549 Albany Street, Boston, MA 02118). The data are presented as the percentage stimulation of specific $\left[{ }^{35} \mathrm{~S}\right] \mathrm{GTP} \gamma \mathrm{S}$ binding over the basal activity and are expressed as the mean values \pm SEM. Each measurement was taken in triplicate and analyzed with the sigmoid dose-response curve fitting option of the GraphPad Prism software (version 4.0, San Diego, CA,
USA) to obtain values for potency $\left(E_{50}\right)$ and efficacy $\left(\mathrm{E}_{\max }\right)$.

\section{Results}

The synthetic peptide was selected for tritium labeling (Table I). The precursor peptide H-Lys-plPhe-pIPhe-Gly-Leu-Met- $\mathrm{NH}_{2}$ was catalytically dehalogenated under tritium gas to yield the radioligand $\mathrm{H}$-Lys-[ $\left[{ }^{3} \mathrm{H}\right]$ Phe- $\left[{ }^{3} \mathrm{H}\right]$ Phe-Gly-Leu-Met- $\mathrm{NH}_{2}$. This peptide was found to have a specific activity of $24 \mathrm{Ci} / \mathrm{mmol}$ (0.89 TBq/mmol). To prevent methionine oxidation and other side reactions, the radioligand was dissolved and stored in spectroscopic grade ethanol containing $0.1 \mathrm{mM}$ L-Met as a stabilizing agent.

The kinetic and pharmacological properties of the new radioligand were defined using various receptor binding techniques in rat brain membrane homogenate as the biological matrix. Kinetic parameters ( $\mathrm{k}_{\mathrm{a}}$ and $\mathrm{k}_{\mathrm{d}}$ rate constants, $\mathrm{K}_{\mathrm{d}}$ and $\mathrm{B}_{\max }$ values) were determined from association, dissociation and saturation experiments. Association binding experiments were carried out with $2.0 \mathrm{nM}$ radioligand at $25^{\circ} \mathrm{C}$ in rat brain membrane homogenate. Specific binding reached a steady state within 20-30 minutes (Fig. 1A) and remained stable for 60 minutes. Non-specific binding was approximately $50-60 \%$ of total binding in all cases under equilibrium conditions (not shown). The pseudo-first order rate constant was found to be approximately $0.1805 \pm 0.023 \mathrm{~min}^{-1}$. The association rate constant, $\mathrm{k}_{\mathrm{a}}$, was determined from this value to be $0.0181 \pm 0.0009 \mathrm{nM}^{-1} \mathrm{~min}^{-1}$ (Table II). Dissociation was measured by pre-incubating the radioligand with the receptor until equilibrium; subsequent addition of $10 \mu \mathrm{M}$ unlabeled ligand initiated dissociation (Fig. 1B). The dissociation isotherm followed monophasic kinetics and provided a dissociation rate constant $\left(k_{d}\right)$ of $0.1263 \pm 0.0422$ $\mathrm{min}^{-1}$. The equilibrium dissociation constant $\left(\mathrm{K}_{\mathrm{d}}\right)$, calculated from these two rate constants, was found to be $6.9 \pm 1.8 \mathrm{nM}$. The saturation isotherm showed that the specific binding of $\left[{ }^{3} \mathrm{H}\right]-\mathrm{KFFGLM}-\mathrm{NH}_{2}$ was

Table I. Analytical data for synthetic peptides

\begin{tabular}{|lccc|}
\hline Sequence of peptides & \multicolumn{2}{c|}{$\mathrm{RT}^{\mathrm{a}}$} & \multicolumn{2}{c|}{ ESI-MS } \\
\cline { 2 - 4 } & & {$\left[\mathrm{M}+\mathrm{H}^{+}\right]_{\text {calc }}$} & {$\left[\mathrm{M}+\mathrm{H}^{+}\right]_{\text {found }}$} \\
\hline H-Lys-Phe-Phe-Gly-Leu-Met-NH ${ }_{2}$ & 12.3 & 741.9 & 741.9 \\
\hline H-Lys-plPhe-pIPhe-Gly-Leu-Met-NH ${ }_{2}$ & 13.9 & 993.7 & 993.7 \\
\hline
\end{tabular}

${ }^{a}$ Gradient 3-97\% ACN in $30 \mathrm{~min}$, flow $1 \mathrm{ml} / \mathrm{min}$, eluents: $\mathrm{H}_{2} \mathrm{O}$ and $\mathrm{ACN}$ both containing $0.05 \%(\mathrm{~V} / \mathrm{V})$ TFA 
A

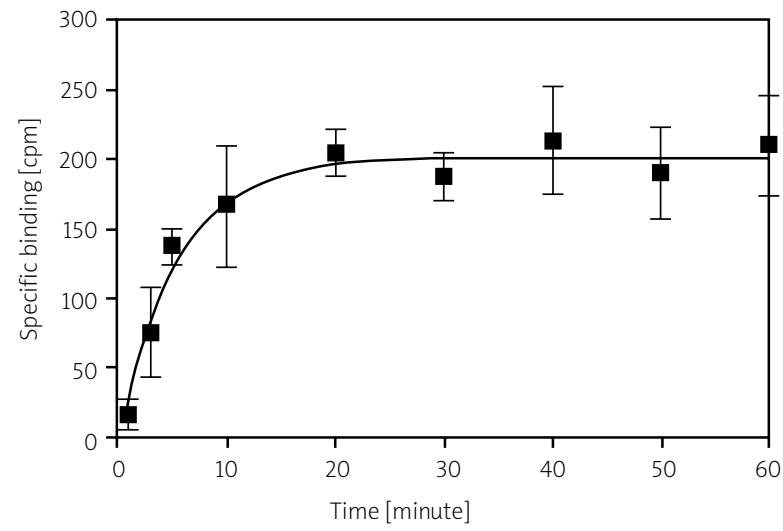

B

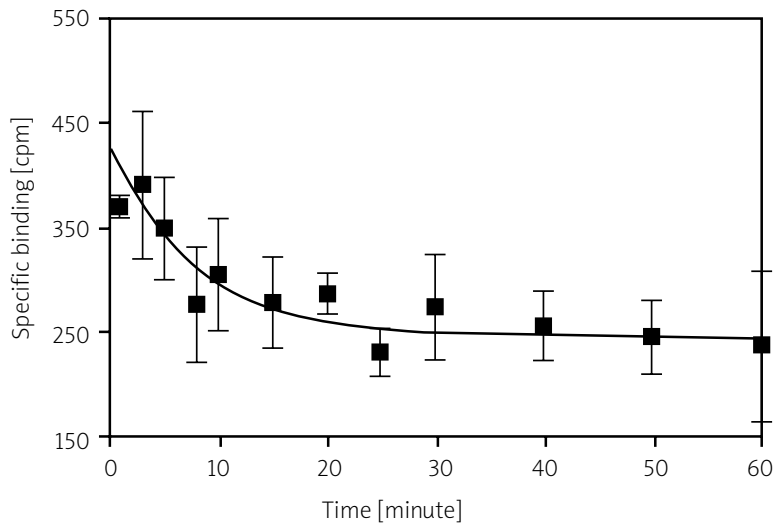

Fig. 1. Association and dissociation time courses of $\left[{ }^{3} \mathrm{H}\right]-\mathrm{KFFGLM}-\mathrm{NH}_{2}$ binding at $25^{\circ} \mathrm{C}$. A) $2.0 \mathrm{nM}$ radioligand was incubated with rat brain membrane for 60 minutes until the system reached equilibrium. B) $2.0 \mathrm{nM}$ radioligand was pre-incubated with rat brain membrane for 60 minutes followed by addition of $10 \mu \mathrm{M}$ unlabeled $\mathrm{H}-\mathrm{KFFGLM}-\mathrm{NH}_{2}$ to induce dissociation. Dissociation was complete after 60 minutes. Only specific binding is reported.

a high-affinity, saturable interaction (Fig. 2). Fitting the direct saturation plot to a "one-site" binding model gave a $\mathrm{K}_{d}$ of $7.1 \pm 2.2 \mathrm{nM}$, which was in good agreement with that determined from the kinetic curves (Table II). Receptor density $\left(B_{\max }\right)$ was calculated to be $257 \pm 46 \mathrm{fmol} \times \mathrm{mg}$ protein ${ }^{-1}$, a value that is several orders of magnitude greater than those reported in the literature for substance $P$ (SP) [20].

The sites on the receptor where the radioligand binds were characterized through displacement binding experiments using receptor selective competitors of the radioligand in rat brain membrane homogenates (Fig. 3A-C). The inhibitory constants

Table II. Kinetic binding parameters for $\left[{ }^{3} \mathrm{H}\right]-\mathrm{KFF}-$ $\mathrm{GLM}-\mathrm{NH}_{2}$

\begin{tabular}{|c|c|}
\hline Kinetic parameters & \\
\hline $\mathrm{k}_{\mathrm{obs}}\left(\mathrm{min}^{-1}\right)$ & $0.1805 \pm 0.023$ \\
\hline $\mathrm{k}_{\mathrm{a}}\left(\mathrm{n} \mathrm{M}^{-1} \times \mathrm{min}^{-1}\right)$ & $0.0181 \pm 0.0009$ \\
\hline$k_{d}\left(\min ^{-1}\right)$ & $0.1263 \pm 0.0422$ \\
\hline $\mathrm{K}_{\mathrm{d}}(\mathrm{nM})$ & $6.9 \pm 1.8$ \\
\hline$K_{d}^{*}(n M)$ & $7.1 \pm 2.2^{*}$ \\
\hline $\mathrm{B}_{\max }\left(\mathrm{fmol} \times \mathrm{mg}\right.$ protein $\left.^{-1}\right)$ & $257 \pm 46$ \\
\hline
\end{tabular}

The observed pseudo-first order rate constant $\left(k_{o b s}\right)$ was derived from the association curve. Values for the dissociation $\left(k_{d}\right)$ and association $\left(k_{d}\right)$ rate constants were calculated according to the following equation: $k_{a}=\left(k_{\text {obs }}-k_{d}\right) /$ [radioligand]. $K_{d}$ was calculated as follows: $K_{d}=k_{d} / k_{a}$. Receptor density ( $B_{\max }$ ) and equilibrium dissociation constant $\left(K_{d}^{*}\right)$ were calculated from the saturation plot. The data are expressed as the mean values $\pm S E M, n \geq 5$.
$\left(\mathrm{K}_{\mathrm{i}}\right)$ determined through these experiments are summarized in Table III. The majority of neurokinin receptor specific ligands displaced the radioligand with micromolar inhibitory constants $\left(\mathrm{K}_{\mathrm{i}}-\mu \mathrm{M}\right)$ reflecting the low affinity of the radioligand for these receptors. This contrasts markedly with literature data reported for SP $[17,20]$. The highest affinity was found for the non-peptidic NK-1 receptor antagonist

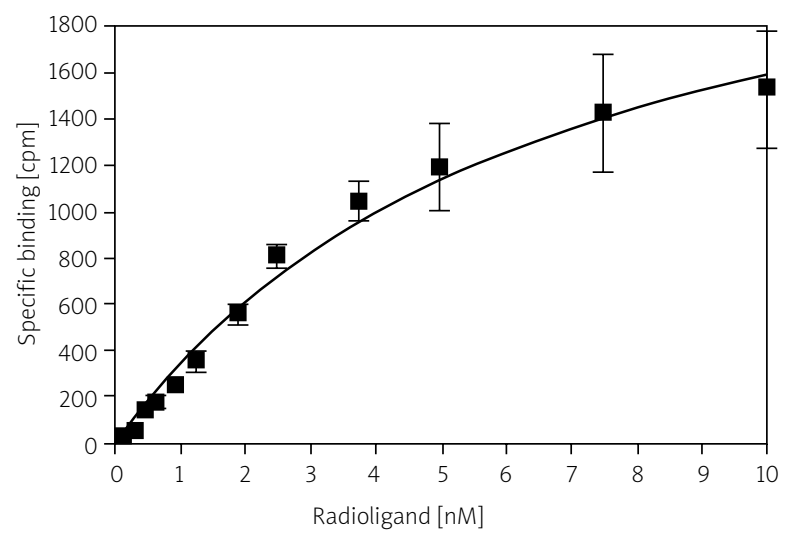

Fig. 2. Saturation isotherm of $\left[{ }^{3} \mathrm{H}\right]-\mathrm{KFFGLM}-\mathrm{NH}_{2}$. Increasing concentrations of radioligand (0.1$10 \mathrm{nM}$ ) were incubated with rat brain membrane as described in the Material and methods section. Values for the dissociation equilibrium constant $\left(\mathrm{K}_{\mathrm{d}}\right)$ and receptor density $\left(\mathrm{B}_{\max }\right)$ were determined directly from the saturation plot. The value of $B_{\max }$ was then converted to fmol $\times \mathrm{mg}$ protein $^{-1}$. Only specific binding is reported. 
A

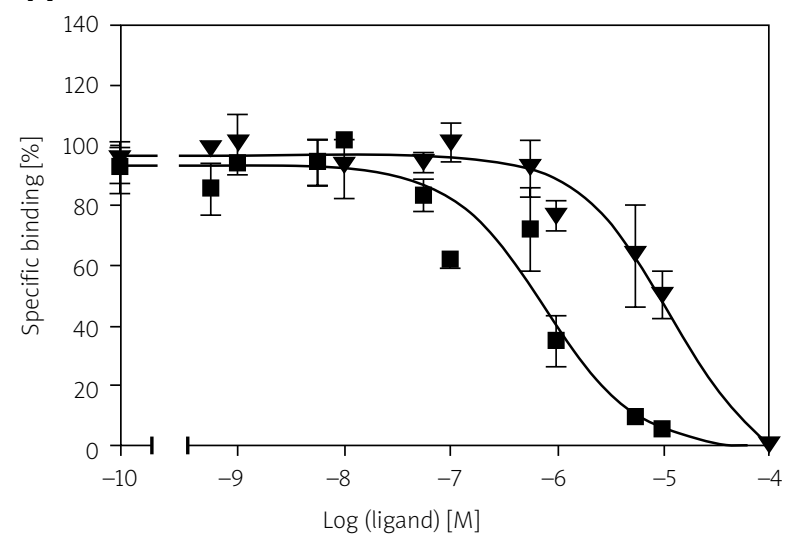

C

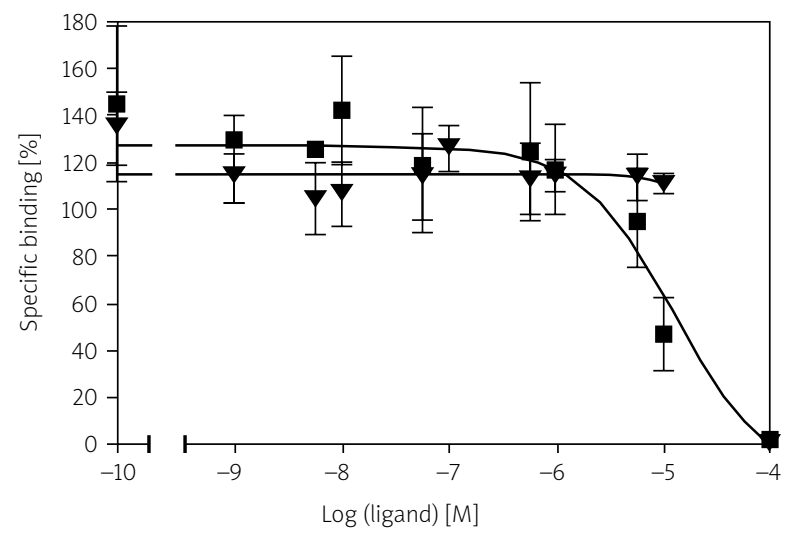

Table III. Inhibitory constants $\left(\mathrm{K}_{\mathrm{i}}\right)$ for NK-1, -2 and -3 receptor specific unlabeled ligands against radiolabeled $\left[{ }^{3} \mathrm{H}\right]-\mathrm{KFFGLM}-\mathrm{NH}_{2}$

\begin{tabular}{|c|c|}
\hline Ligands & $\mathrm{K}_{\mathrm{i}}(\mu \mathrm{M})$ \\
\hline H-Lys-Phe-Phe-Gly-Leu-Met- $\mathrm{NH}_{2}$ & $0.58 \pm 0.10$ \\
\hline $\begin{array}{l}\text { Substance } \mathrm{P}(\mathrm{NK}-1>\mathrm{NK}-2 \geq \mathrm{NK}-3 \text {, } \\
\text { non-selective agonist) }\end{array}$ & $5.98 \pm 1.39$ \\
\hline L-703,606 oxalate (NK-1 antagonist) & $0.08 \pm 0.01$ \\
\hline$\left(\mathrm{Nle}^{10}\right)$-neurokinin $\mathrm{A}$ (4-10) (NK-2 agonist) & - \\
\hline 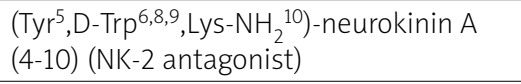 & $1.39 \pm 0.65$ \\
\hline (Pro7)-neurokinin B (NK-3 agonist) & $3.78 \pm 0.54$ \\
\hline $\begin{array}{l}\left(\operatorname{Trp}^{7}, \beta-\text { Ala }^{8}\right) \text {-neurokinin A }(4-10) \\
\text { (NK-3 antagonist) }\end{array}$ & - \\
\hline
\end{tabular}

Inhibitory constants $(K)$ were calculated according to the Cheng-Prusoff equation: $K_{i}=E C_{50} /\left(1+[\right.$ ligand $\left.] / K_{d}\right)$, where $K_{d}=7 \mathrm{nM}$ was deduced from kinetic experiments. The data are expressed as the mean values $\pm S E M, n \geq 5$

L-703,606 oxalate, which inhibits radioligand binding with a $\mathrm{K}_{\mathrm{i}}$ value of $0.087 \pm 0.016 \mu \mathrm{M}$. This $\mathrm{K}_{\mathrm{i}}$ is more potent than that observed for the unlabeled analogue
B

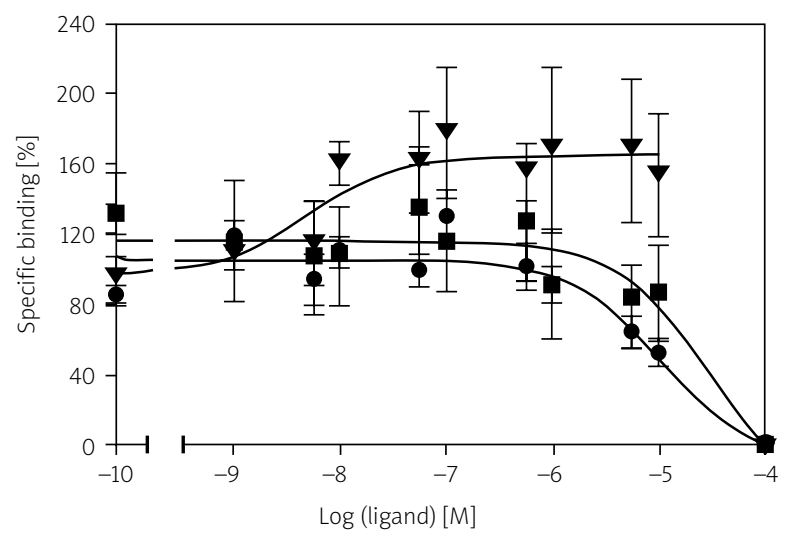

Fig. 3. Homologous and heterologous competitive displacement of $\left[{ }^{3} \mathrm{H}\right]-\mathrm{KFFGLM}-\mathrm{NH}_{2}$ binding by neurokinin receptor specific (NK-1, -2,-3) agonist or antagonist ligands. Rat brain membranes were incubated with $6 \mathrm{nM}$ radioligand in the presence of $10^{-10}-10^{-5} \mathrm{M}$ of the following competitors: A) H-KFFGLM-NH ${ }_{2}(\mathbf{\square})$,

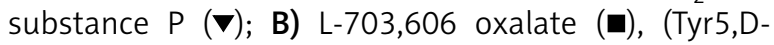
Trp6,8,9, Lys-NH210)-neurokinin A (4-10) (•), (Nle10)-

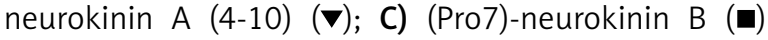
and (Trp7,ß-Ala8)-neurokinin A (4-10) ( $\mathbf{\nabla})$. Non-specific binding was measured with $10 \mu \mathrm{M} \mathrm{H}$-KFFGLM-NH${ }_{2}$ and was subtracted. Specific binding in the absence of competitors was defined as $100 \%$.

of the radioligand $\left(\mathrm{K}_{\mathrm{i}}=0.580 \pm 0.103 \mu \mathrm{M}\right)$. Other derivatives proved to be poor inhibitors of radioligand binding, suggesting that truncation of neurokinin $\mathrm{N}$-terminal sequences is not favorable for selective receptor-ligand interactions. Interestingly, unusual behavior was observed for two receptor selective ligands and receptor types. Positive cooperativity could be observed for a peptidic NK-2 agonist, ( $\mathrm{Nle}^{10}$ )-neurokinin A (4-10) (Fig. 3B). Increasing the concentration of $\left(\mathrm{Nle}^{10}\right)$-neurokinin $\mathrm{A}(4-10)$ to $10^{-5} \mathrm{M}$ while maintaining a constant radioligand concentration led to a massive accumulation of radioligand. This outcome manifests itself in an "inverse" behavior. This feature suggests the likelihood of positive allosteric modulation, the existence of multiple binding sites or multiple conformational states of the receptor protein. Any of these could trigger concomitant binding of two different ligands, likely at two distinct binding sites. This is very interesting given that the analysis of kinetic data using the "two site" binding model for the radioligand failed to provide 
meaningful values. In contrast, no competition was observed between the radioligand and the NK-3 antagonist ( $\left.\operatorname{Trp}^{7}, \beta-A l a^{8}\right)$-neurokinin A (4-10), whereas competition with an NK-3 selective agonist was observed. These results show that the antagonist cannot reverse the binding of the radioligand at any concentration. Consequently, the radioligand and antagonist may not occupy the same binding sites. This finding further supports the hypothesis that the radioligand may bind to distinct binding sites or conformational states of the receptor protein, different from those of the receptor selective competitors.

The functional properties of the H-KFFGLM-NH hexapeptide were investigated in a ligand-stimulated $\left[{ }^{35} \mathrm{~S}\right] \mathrm{GTP} \gamma \mathrm{S}$ functional binding assay, which revealed the ability of NK ligands to activate $G$ proteins. Potency $\left(\mathrm{EC}_{50}\right)$ and efficacy $\left(\mathrm{E}_{\text {max }}\right)$ values were compared with those for the prototypic NK receptor agonist SP (Fig. 4, Table IV). Both ligands showed potency toward activation of $G$ proteins, with $\mathrm{EC}_{50}$ values of $313 \pm 36 \mathrm{nM}\left(\mathrm{H}-\mathrm{KFFGLM}-\mathrm{NH}_{2}\right)$ and 892 $\pm 65 \mathrm{nM}$ (SP). The corresponding efficacies were found to be $142 \pm 9 \%\left(\mathrm{H}-\mathrm{KFFGLM}-\mathrm{NH}_{2}\right)$ and 120 $\pm 4 \%$ (SP). These results strongly suggest that the ligands are agonists of the NK receptors, indicating that targeted $N$-terminal truncation and modifica- tion of SP do not profoundly influence its functional properties. The relatively low efficacy found for SP may be attributed to the presence of fewer NK-1 binding sites in rat brain compared with the number of primary sites in the spinal cord. The functional data measured for the co-application of receptor antagonists and $\mathrm{H}-\mathrm{KFFGLM}-\mathrm{NH}_{2}$ confirmed that the hexapeptide binds to neurokinin receptors and activates G-protein coupling that could be abrogated by the selective antagonists.

\section{Discussion}

Numerous structure-activity relationship studies have shown that the $C$-terminal component of neurokinin ligands (especially the $C$-terminal pentapeptide Phe-X-Gly-Leu-Met- $\mathrm{NH}_{2}$ motif, where $X$ is a hydrophobic amino acid residue) is critical for specific binding of high-affinity agonists to receptors in the tachykinin family $[4,20,22,26,27,33]$.

All C-terminal tachykinin fragments interact with similar binding sites of their receptors. For these fragments there exist some common structural requirements. For example, peptide mapping studies of the $\mathrm{NK}_{1}$ receptor have established that the site of interactions of both SP and NKA is located within the same segment of the receptor [3,33].
A

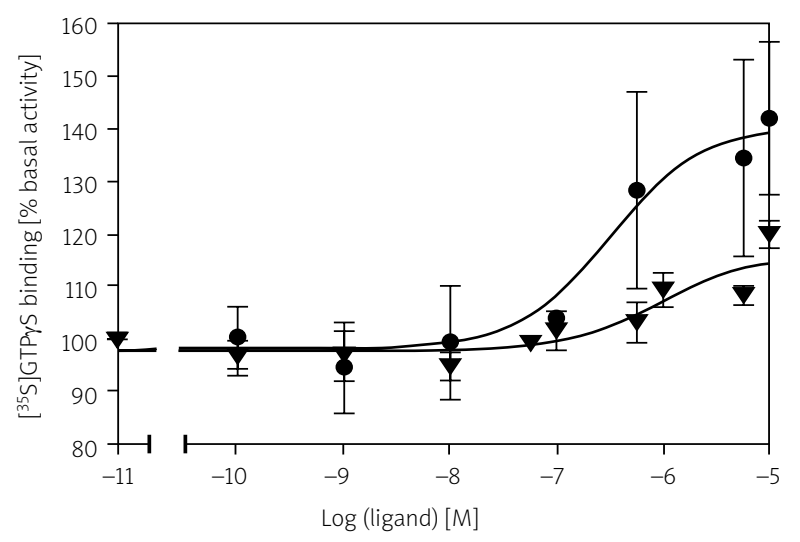

B

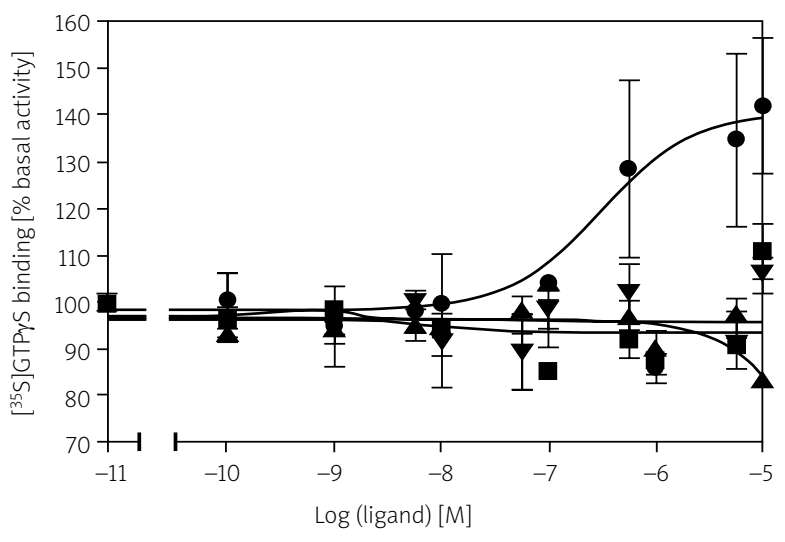

Fig. 4. Stimulation of guanine nucleotide binding to the NK receptors by $\mathrm{H}-\mathrm{KFFGLM}-\mathrm{NH}_{2}$ and substance $P$ in the absence or presence of receptor specific antagonists: A) H-KFFGLM-NH $\mathrm{N}_{2}(\bullet)$ and substance $\mathrm{P}(\boldsymbol{\nabla})$;

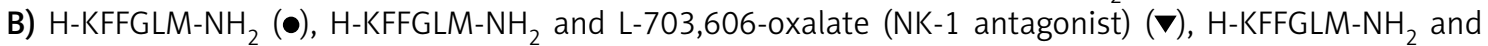
(Tyr ${ }^{5}, \mathrm{D}-\mathrm{Trp}^{6,8,9}$,Lys-NH2 ${ }^{10}$ )-neurokinin A (4-10) (NK-2 antagonist) ( $\left.\mathbf{\square}\right) ; \mathrm{H}-\mathrm{KFFGLM-NH}{ }_{2}$ and (Trp $\left.{ }^{7}, \beta-A l a^{8}\right)$-neurokinin A (4-10) (NK-3 antagonist) ( $\boldsymbol{\nabla}$ ). Rat brain membranes were incubated with $0.05 \mathrm{nM}\left[{ }^{35} \mathrm{~S}\right] \mathrm{GTP} \gamma \mathrm{S}$ and NK ligands at various concentrations. Stimulation of $\left.{ }^{35} \mathrm{~S}\right] \mathrm{GTP} \gamma \mathrm{S}$ binding was measured and evaluated as described in the Material and methods section. The data are expressed as the percentage stimulation of basal activities and reported as the mean values \pm SEM, $n \geq 4$, each performed in triplicate. 
Table IV. Summary of $\left.{ }^{35} \mathrm{~S}\right] \mathrm{GTP} \gamma \mathrm{S}$ functional assays performed with $\mathrm{H}-\mathrm{KFFGLM}-\mathrm{NH}_{2}$ in the absence or presence of receptor selective antagonists in rat brain membrane preparation

\begin{tabular}{|c|c|c|}
\hline Peptides & $\mathrm{EC}_{50}(\mathrm{nM})$ & $\mathrm{E}_{\max }(\%)$ \\
\hline $\mathrm{H}-\mathrm{KFFGLM}-\mathrm{NH}_{2}$ & $313 \pm 36$ & $142 \pm 9$ \\
\hline Substance P (NK-1 $\geq$ NK-2 NK-3 agonist) & $892 \pm 65$ & $120 \pm 4$ \\
\hline H-KFFGLM-NH $2+$ L-703,606 (NK-1 antagonist) & n.a. & n.a. \\
\hline H-KFFGLM-NH ${ }_{2}+\left(\operatorname{Tyr}^{5}, \mathrm{D}-\operatorname{Trp}^{6,8,9}\right.$, Lys-NH2 $\left.^{10}\right)$-neurokinin A (4-10) (NK-2 antagonist) & n.a. & n.a. \\
\hline $\mathrm{H}-\mathrm{KFFGLM}-\mathrm{NH}_{2}+\left(\operatorname{Trp}^{7}, \beta-\mathrm{Ala}^{8}\right)$-neurokinin A (4-10) (NK-3 antagonist) & n.a. & n.a. \\
\hline
\end{tabular}

Values for $E C_{50}$ and $E_{\text {max }}$ were calculated by GraphPad Prism software using the "sigmoid dose-response" fitting option. All three antagonists could completely block the stimulatory effect of H-KFFGLM-NH $\mathrm{N}_{2}$ (no functional data could be determined) even at low $\left(10^{-6} \mathrm{M}\right)$ antagonist concentrations. The data are expressed as percentage stimulation of basal activities and are mean values $\pm S E M, n \geq 4$, each performed in triplicate.

The $N$-terminal fragments of tachykinins play a role in modulating the selectivity of endogenous ligands by decreasing or increasing affinities to particular NK receptor types. In addition, $N$-terminal fragments can carry out their independent neuromodulatory functions in intact endogenous peptides or as metabolites [8]. Our strategy was to truncate and modify the structure of the $C$-terminal fragment of an NK receptor agonist to prepare a tractable radioligand that could be used to investigate the tachykinin system. Our results further confirmed the fact that subtle differences in structure and chain length can result in striking changes in the mode of ligand binding, and presumably have an effect on GPCR signaling. The first intriguing finding came from kinetic experiments, which revealed unusually high receptor density $\left(B_{\max }\right)$ and a relatively high value for $\mathrm{K}_{d}$ compared with those reported for SP in rat brain [20]. Park et al. (1984) reported a single high affinity $\left(\mathrm{K}_{\mathrm{d}}=0.3 \mathrm{nM}\right)$ and low density $\left(\mathrm{B}_{\max }=27.7\right.$ fmol $\mathrm{mg}$ protein ${ }^{-1}$ ) class of binding sites for SP in rat brain. Additionally, the relative potencies of various SP fragments for $\left[{ }^{3} \mathrm{H}\right]$-SP binding sites were found to be roughly proportional to the length of the C-terminal fragments. We hypothesize from these data that the hexapeptide binds to multiple regions, conformational states or subtypes/splice variants of the receptor proteins. Some of these binding sites may not be identical to the "conventional" binding sites or conformational states for the endogenous neurokinin ligands or receptors. The existence of two different binding sites has already been proposed by Sagan et al. as the major binding site (labeled with [[3 $\left.{ }^{3}\right]$ Pro9]SP) and the minor binding site (labeled with [[3 $\left.{ }^{3} \mathrm{H}\right]$ propionyl-Met $\left.\left(\mathrm{O}_{2}\right) 11\right] \mathrm{SP}-(7-11)$, respectively [24]. The differences have been further confirmed by displacement experiments, which revealed that binding of $\left[{ }^{3} \mathrm{H}\right]-\mathrm{KFFGLM}-\mathrm{NH}_{2}$ could be fully abrogated by the addition of $\mathrm{H}-\mathrm{KFFGLM}-\mathrm{NH}_{2}$, but not by any of the antagonists. The micromolar inhibitory constants $\left(\mathrm{K}_{\mathrm{i}}\right)$ measured for the radioligand in competition with receptor selective antagonists for binding to NK receptors also support this hypothesis. Indeed, there are several lines of evidence that support the existence of different binding sites, kinetically distinct states of receptors or the involvement of subtypes/splice variants of neurokinin receptors in ligand binding $[9,13,14]$. However, these possibilities have yet to be explored.

The $N$-terminally truncated and modified hexapeptide retained its functional agonist activity and stimulated G-protein coupling. Its overall behavior was similar to that observed for the parent peptide SP. The increased potency and efficacy of H-KFF$\mathrm{GLM}-\mathrm{NH}_{2}$ over those of SP also suggest a different mode of ligand binding. However, all of the NK-receptor antagonists could inhibit ligand activity at relatively low concentrations. While it has yet to be investigated, it is possible that ligand binding may alter G-protein signaling. It has also been demonstrated that the endogenous or exogenous ligands for neurokinin receptors can induce conformational state-dependent or ligand binding-dependent modulation of various signal transduction pathways. This can lead to such diverse responses as calcium release and CAMP production, or initiation of receptor desensitization [18,21,23,29]. In addition, derivatives of SP modified at the $C$-terminus have been described that can behave as both agonists and antagonists of the NK-1 receptor, depending on the second messenger pathway $[18,23]$. Taking the literature data and our findings together, we speculate that our ligand interacts with binding sites specific to C-terminal tachykinin binding sites ("tachykinin 
pocket"). These sites are structurally similar for all tachykinin receptors. The endogenous ligands of at least three receptors $\left(\mathrm{NK}_{1}, \mathrm{NK}_{2}\right.$ and $\left.\mathrm{NK}_{3}\right)$ have $\mathrm{N}$-terminal fragments that enhance affinity to one type of receptor while decreasing affinity for other types. Our results may also suggest the existence of other tachykinin binding sites that preferentially recognize the H-KFFGLM-NH $\mathrm{N}_{2}$ motif. However, this binding site (or sites) is characterized by broad recognition of all tachykinin ligands and attenuated recognition of the $\mathrm{N}$-terminal fragments that usually increase ligand selectivity and affinity.

Mysteriously, two previously observed specific binding sites are not present in stable equivalent amounts, suggesting the influence of other modulatory elements [25]. All interpretations of previous observations of various binding sites have been constructed with prediction of tachykinin receptors' existence in monomeric form. However, in the light of our data, we hypothesize that dimers of NK receptors could be specific receptor(s) for C-terminal fragments, including $\mathrm{H}-\mathrm{KFFGLM}-\mathrm{NH}_{2}$. Previous discussions on other types of GPCR led to the suggestion that dimerization of receptors may result in the formation of an additional allosteric binding site or sites [30]. It should also be considered that interaction of receptor domains in the dimerization process may also destroy "allosteric pockets" as the result of structural reorganization required to form a dimeric macromolecule (Fig. 5). In such a case, C-terminal hexapeptide fragment analogues may have less specific interactions with all tachykinin receptors in both monomeric and dimeric forms. Fully elongated undecapeptide substance $P$ interacts with both the "tachykinin pocket" and the "allosteric pocket" on the monomeric NK1 receptor (Fig. 5A). Interactions with the dimeric form are limited to the "tachykinin pockets". The obtained results on pharmacological
A

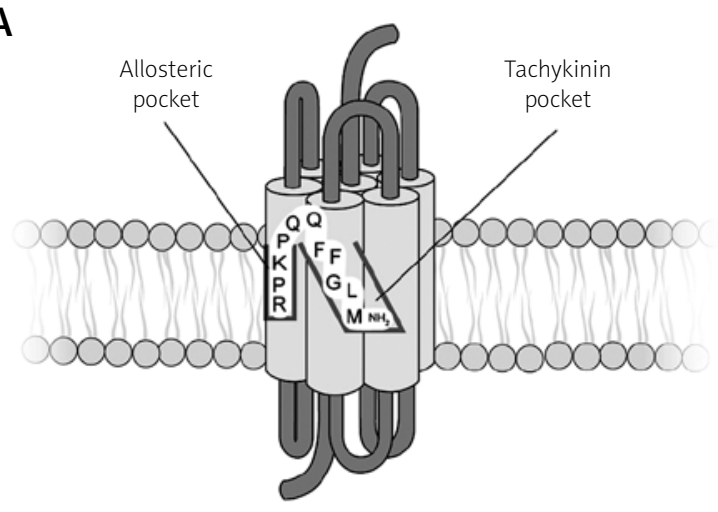

B

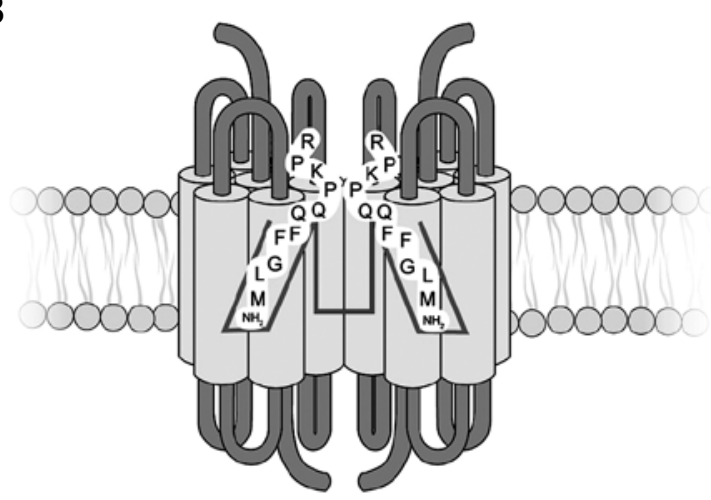

A1

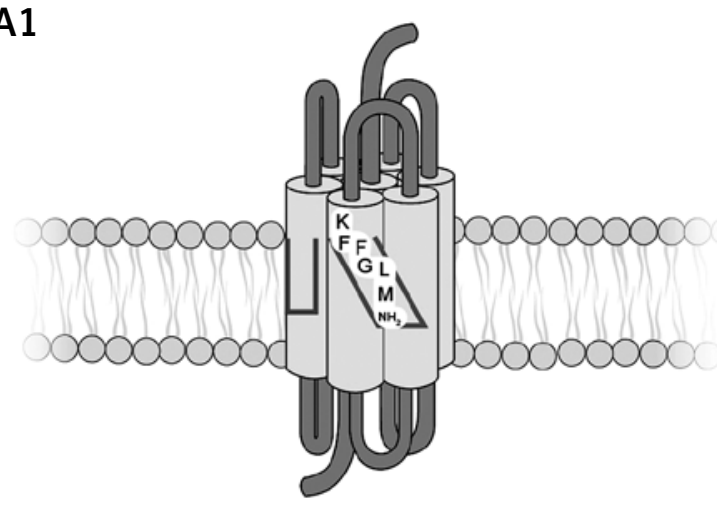

B1

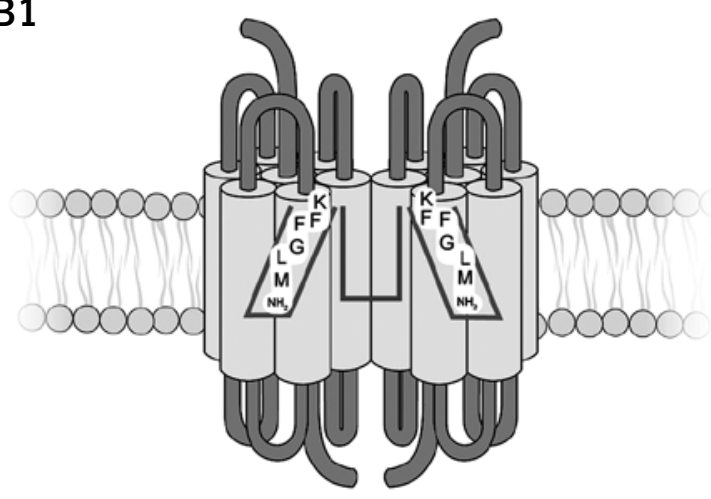

Fig. 5. Illustration of substance $P$ interacting with monomeric and dimeric $\mathrm{NK}_{1}$ receptor. In the monomer, the interaction of the $C$-terminal fragment of substance $P$ with the "tachykinin pocket" is enhanced by allosteric interaction of the $N$-terminal fragment with the "allosteric pocket". Dimerization of receptors blocks the "allosteric pockets". "Tachykinin pockets" in the monomeric and dimeric forms are recognized equally well by KFFGLM-NH${ }_{2}$. 
properties of $\mathrm{H}-\mathrm{KFFGLM}-\mathrm{NH}_{2}$ were quite unexpected. This allowed us to construct the working hypothesis. However, for confirmation it is necessary to define a new avenue of investigation that will be explored in our further studies.

\section{Acknowledgments}

Aleksandra Tomczyszyn and Balazs Csibran contributed equally to this paper. The technical assistance of Ildiko Nemethne is acknowledged and greatly appreciated. This research was carried out using the TET 10-1-2011-055 grant, CePT infrastructure financed by the European Union - the European Regional Development Fund within the Operational Programme "Innovative Economy" for 2007-2013, Mazowia Peptide Klaster, a Polish-Hungarian bilateral collaboration program, a PolishHungarian bilateral collaboration program and COST Action CM1207-GLISTEN. Part of the study was carried out at the Biological and Chemical Research Centre, University of Warsaw, established within the project co-financed by the European Union from the European Regional Development Fund under the Operational Programme Innovative Economy, 2007-2013.

\section{Disclosure}

Authors report no conflict of interest.

\section{References}

1. Bernardi L, Bosisio G, Chillemi F, de Caro G, de Castiglione R, Erspamer V, Glaesser A, Goffredo O. Synthetic peptides related to eledoisin. Experientia 1964; 20: 306-309.

2. Bozó B, Fülöp F, Tóth GK, Tóth G, Szücs M. Synthesis and opioid binding activity of dermorphin analogues containing cyclic $\beta$-amino acids. Neuropeptides 1997; 31: 367-373.

3. Bremer AA, Leeman SE, Boyd ND. The common C-terminal sequences of substance $P$ and neurokinin $A$ contact the same region of the NK-1 receptor. FEBS Lett 2000; 486: 43-48.

4. Cascieri MA, Huang RR, Fong TM, Cheung AH, Sadowski S, Ber E, Strader CD. Determination of the amino acid residues in substance $\mathrm{P}$ conferring selectivity and specificity for the rat neurokinin receptors. Mol Pharmacol 1992; 41: 1096-1099.

5. Cheng Y, Prusoff WH. Relationship between the inhibition constant (K1) and the concentration of inhibitor which causes 50 percent inhibition (IC50) of an enzymatic reaction. Biochem Pharmacol 1973; 22: 3099-3108.

6. Foran SE, Carr DB, Lipkowski AW, Maszczynska I, Marchand JE, Misicka A, Beinborn M, Kopin A, Kream RM. Substance P-opioid chimeric peptide as a novel non-tolerance forming analgesic. Proc Natl Acad Sci USA 2000; 97: 7621-7626.

7. Foran SE, Carr DB, Lipkowski AW, Maszczynska I, Marchand JE, Misicka A, Beinborn M, Kopin A, Kream RM. Inhibition of mor- phine tolerance development by a substance P-opioid peptide chimera. J Pharmacol Exp Ther 2000; 295: 1142-1148.

8. Fransson R, Botros M, Sköld C, Nyberg F, Lindeberg G, Hallberg M, Sandström A. Discovery of dipeptides with high affinity to the specific binding site for substance P1-7. J Med Chem 2010; 53: 2383-2389.

9. Kim HR, Lavielle S, Sagan S. The two NK-1 binding sites are distinguished by one radiolabed substance $P$ analogue. Biochem Biophys Res Com 2003; 306: 725-729.

10. Kleczkowska P, Lipkowski AW, Tourwe D, Ballet S. Hybrid opioid/ non-opioid ligands in pain research. Curr Pharm Des 2013; 19 : 7435-7450.

11. Lipkowski AW, Carr DB, Bonney I, Kosson P. Opioid-Substance P chimeric peptides. In: Kastin AJ (ed.). Handbook of Biologically Active Peptides. $2^{\text {nd }}$ ed. Academic Press, San Diego 2013; pp. 1586-1591.

12. Lipkowski AW, Carr DB. Neuropeptides: Peptide and Neuropeptide Analogs. In: Peptides - Synthesis and Applications. In: Gutte B (ed.). Academic Press, London 1995; pp. 287-320.

13. Liu L, Markus I, Vandenberg RJ, Neilan BA, Murray M, Burcher E. Molecular identification and characterization of three isoforms of tachykinin NK(1)-like receptors in the cane toad Bufo marinus. Am J Physiol Regul Integr Comp Physiol 2004; 287: R575-585.

14. Maillet EL, Pellegrini N, Valant C, Bucher B, Hibert M, Bourguignon JJ, Galzi JL. A novel conformation-specific allosteric inhibitor of the tachykinin NK2 receptor (NK2R) with functionally selective properties. FASEB J 2007; 21: 2124-2134.

15. Maszczynska Bonney I, Foran SE, Marchand JE, Lipkowski AW, Carr DB. Spinal antinociceptive effects of AA501, a novel chimeric peptide with opioid receptor agonist and tachykinin receptor antagonist moieties. Eur J Pharmacol 2004; 488: 91-99.

16. Matalinska J, Skurzak H, Markowicz S, Lesniak A, Sacharczuk M, Molnar G, Varga E, Lipkowski AW. Opioid agonist - tachykinin antagonist as a new analgesic with adjuvant anticancer properties. Folia Neuropathol 2013; 51: 132-139.

17. Mazzone SB, Hinrichsen CF, Geraghty DP. Substance P receptors in brain stem centers of the rat: regulation of NK1 receptors by hypoxia. J Pharmacol Exp Ther 1997; 282: 1547-1556.

18. Michael-Titus AT; Blackburn D, Connolly Y, Priestley JV, Whelpton R. N- and C-terminal substance $P$ fragments: differential effects on striatal $[3 \mathrm{H}]$ substance $P$ binding and NK1 receptor internalization. Neuroreport 1999; 10: 2209-2213.

19. Page NM. Brain Tachykinins. In: Kastin AJ (ed.). Handbook of Biologically Active Peptides. $2^{\text {nd }}$ ed. Academic Press, San Diego 2013; pp. 943-950.

20. Park CH, Massari VJ, Quirion R, TizabiY, Shults CW, O'Donohue TL. Characteristics of $3 \mathrm{H}$-substance $P$ binding sites in rat brain membrane. Peptides 1984; 4: 833-836.

21. Perrine SA, Beard DJ, Young JK, Simmons MA. The role of the $\mathrm{N}$-terminal and mid-region residues of substance $\mathrm{P}$ in regulation functional selectivity at the tachykinin NK1 receptor. Eur J Pharmacol 2008; 592: 1-6.

22. Quancard J, Karoyan P, Sagan S, Convert O, Lavielle S, Chassaing G, Lequin O. Characterization of the bioactive conformation of the C-terminal tripeptide Gly-Leu-Met-NH2 of substance P using [3-prolinoleucin10]SP analogues. Eur J Biochem 2003; 270: 28692878. 
23. Sachon E, Girault-Lagrange S, Chassaing G, Lavielle S, Sagan S. Analogs of substance P modified at the C-terminus which are both agonist and antagonist of the NK-1 receptor depending on the second messenger pathway. J Pept Res 2002; 59: 232-240.

24. Sagan S, Beaujouan J-C, Torrens Y, Saffroy M, Chassaing G, Glowinski J, Lavielle S. High affinity binding of [3H]propionyl[Met(O2)11] substance P(7-11), a tritiated septide-like peptide, in Chinese hamster ovary cells expressing human neurokinin-1 receptors and in rat submandibular glands. Mol Pharmacol 1997; 52: 120-127.

25. Sagan S, Karoyan P, Chassaing G, Lavielle S. Further delineation of the two binding sites $\left(R^{*} n\right)$ associated with tachykinin neurokinin-1 receptors using [3-prolinomethionine11]SP analogues. J Biol Chem 1999; 274: 23770-23776.

26. Sagan S, Quancard J, Lequin O, Karoyan P, Chassaing G, Lavielle S. Conformational analysis of the C-terminal Gly-Leu-Met-NH2 tripeptide of substance P bound to the NK-1 receptor. Chem Biol 2005; 5: 555-565

27. Severini C, Improta G, Falconieri-Erspamer G, Salvatori S, Erspamer V. The tachykinin peptide family. Pharmacol Rev 2002; 54: $1-38$.

28. Severini C, Improta G. Tachykinins. In: Handbook of Biologically Active Peptides. Kastin AJ (ed.). $2^{\text {nd }}$ ed. Academic Press, San Diego 2013, pp. 391-399.

29. Simmons MA. Functional selectivity of NK1 receptor signaling: peptide agonist can preferentially produce receptor activation or desensitization. J Pharm Exp Ther 2006; 319: 907-913.

30. Smith NJ, Milligan G. Allostery at G protein-coupled receptor homo- and heteromers: uncharted pharmacological landscapes. Pharmacol Rev 2010; 62: 701-725.

31. Toth G, Mallareddy JR, Toth F, Lipkowski AW, Tourwe D. Radiotracers, tritium labelling of neuropeptides ARKIVOC 2012; 5 : 163-174.

32. Valant C, Maillet E, Bourguignon JJ, Bucher B, Utard V, Galzi J. Allosteric functional switch of neurokininA-mediated signaling at the neurokinin NK2 receptor: Structural exploration. J Med Chem 2009; 52: 5999-6011.

33. Wang J-X, Dipasquale AJ, Bray AM, Maeji NJ, Spellmeyer DC, Geysen HM. Systematic study of substance P analogs. II. Rapid screening of 512 substance P stereoisomers for binding to NK1 receptor. Int J Pept Protein Res 1993; 42: 392-399. 